\title{
Rural change in the context of globalization: examining theoretical issues
}

\author{
Felipe DA SILVA MACHADO ${ }^{1}$
}

\begin{abstract}
Early discussions and theoretical positions concerning rural change were developed by researchers from countries with post-production economies in order to explain the rural transformations. When discussing economic change in rural space over the last decades, MARsden, T. et al. (1993) presented a new perspective for understanding rural restructuring that includes new subjects, such as capital mobility, flexible production regimes, complexity in the relationship between technology and environment, economic deregulation and new political processes. According to these authors, in order to understand such processes, it is necessary to research the effects of globalization at local scale of action. A recurrent theme in rural studies has been the significance of diverse globalization processes as drivers of rural change (MARsden, T. 2003; Robinson, G.M. 2004; Woods, M. 2005, 2007; Ploeg, J.D. vAN DER 2008). Multidimensional and multidirectional perspectives have indicated that rural space has become more embedded within a globalized rural world. Therefore, in recent years, researchers have displayed an interest in understanding the dynamics of the rural spaces in developing countries which are also being affected by global processes in different pathways (WiLson, G.A. and Rigg, J. 2003; RigG, J. 2006; Bryant, C.R. et al. 2008; Ploeg, J.D. van Der et al. 2010). In summary, this article forms a critique of the simplistic assumptions formulated in the literature regarding spatial change, which assumes the rural is essentially subject to external actions. I argue that the rural space should also be seen to possess its own dynamics which contribute to complex pathways and so adapts to new scenarios of spatial change in the contemporary world.
\end{abstract}

Keywords: contemporary rural space, rural change, rural geography, globalization, developing countries

\section{Introduction}

This article provides a framework for understanding rural change, based on an extensive literature review, and discusses the diverse characteristics of this process, primarily in developed countries. It also includes a discussion of rural change and globalization, with a focus on the contemporary conceptual debate concerning rural studies in the global world. As much of the critical literature on rural change and globalization (MARSDEN, T. et al. 1993; Pierce, J.T. 1998; MARsden, T. 2003; Woods, M. 2005, 2007; Bryant, C. et al. 2008) has emphasized, rural studies need greater focus on the diversity of contexts in which rural restructuring takes place. Agricultural and non-agricultural production systems are involved in this process and are interconnected to different degrees, including rural and urban interaction and the articulation of rural dynamics with urban and global dynamics. Last years have probably seen most dramatic changes in rural areas and pace of change appears to accelerate in an increasingly globalised and interlinked world (Robinson, G.M. 2004).

National and regional interests also play an important part, particularly in rural spaces with higher levels of rural and urban interaction, such as occurs with large industrial projects and transport infrastructure that converges on urban agglomerations and connects different regions (BicalHo, A.M.S.M. et al. 1998). Sánchez, G.P.Z. (2000) pointed out that rural spatial transformations caused

\footnotetext{
${ }^{1}$ School of Geography, Earth and Environmental Sciences, Plymouth University, UK. CAPES Foundation, Ministry of Education of Brazil, Brasília - DF Brazil. E-mail: felipe.dasilvamachado@plymouth.ac.uk
} 
by large-scale development projects, such as dams, airports, electric transmission lines, oil exploitation or tourist resorts, imply spatial modifications that, in turn, cause changes and new dynamics in every aspect of local life, generating profound transformations for the rural population.

SÁnchez, H.A. (2012) emphasized the need to create practices that introduce the most inherent aspects of territorial dynamics and that acknowledge the development of endogenous processes, whose actions are crucial for strengthening and consolidating territorial management with the participation of actors in their different economic, political and cultural expressions, notably, in spaces of rural and urban interaction. There is an increased need for understanding governance in spaces where conflict can exist between different agents and institutions involved in concrete territorial processes. Some examples are: "disputes for land and natural resources, real estate speculation for new non-agricultural activities, gentrification, outsourcing of rural space, spatial mobility of rural population or even strengthening the rural land market with new farm activities" (SÁNCHEZ, H.A. 2012, 49). Therefore, the focus on the territorial dimension is crucial for managing and enforcing public policies in multifunctional rural space.

This theoretical debate is based on the critical discussions that have moved away from the rigid notion of simply 'exporting' indicators developed in advanced economies to the developing world situation towards an analytical framework that emphasizes complex rural space. This would mean, I have explored the diverse meanings that have been attached to the recurrent significance of globalization as a driver of rural change, arguing that it needs to be adapted and developed to address conditions found in the developing world. Furthermore, this analysis questions the implied linearity of the traditional concept of rural space and explores different perspectives in human geography. The theoretical discussion is based on debates concerning contemporary rural space with an emphasis on spatial processes and globalization in a rural context (WiLson, G.A. and Rigg, J. 2003; MARsden, T. 2003; Wilson, G.A. 2007, 2012; Woods, M. 2007, 2011).

\section{Understanding rural change}

When discussing economic change in rural space over the last decades, Marsden, T. et al. (1993) emphasized a new perspective for understanding rural restructuring that includes new issues, such as capital mobility, flexible production regimes, complexity in the relationship between technology and environment, economic deregulation and new political processes. According to these authors, in order to understand such processes, it is necessary to research the effects of globalization at local scale of action. Thus, the modes of development that are internal to particular rural areas must be linked to external influences upon such areas.

In geographical theories of rural restructuring since the 1990s the role of local actors has been highlighted, mainly that involving local people transforms rural spaces (BRYANT, C. 1997; Pierce, J.T. 1998; Woods, M. 2005). Structures, other than purely economic ones, are taken into consideration by PRETTY, J.N. (1995), van Huylenbroek, G. et al. (2007) and Wilson, G.A. (2010), allowing for local decision-making, control and management, i.e. focussing on the peculiarities of different kinds of social agents and modalities for organizing rural space. Collective strategic thinking, involving regional institutions and organizations oriented towards territorial development, including the political perspectives of local social actors, is considered to be fundamental for the success of governance (Photo 1).

Local development may be deemed the coherent initiatives and actions, based on the mobilization of local social actors who agree to contribute expertise and assistance for improving specific territories. "Actors or a group of actors may contribute in all four functions necessary and required for developing a ter- 


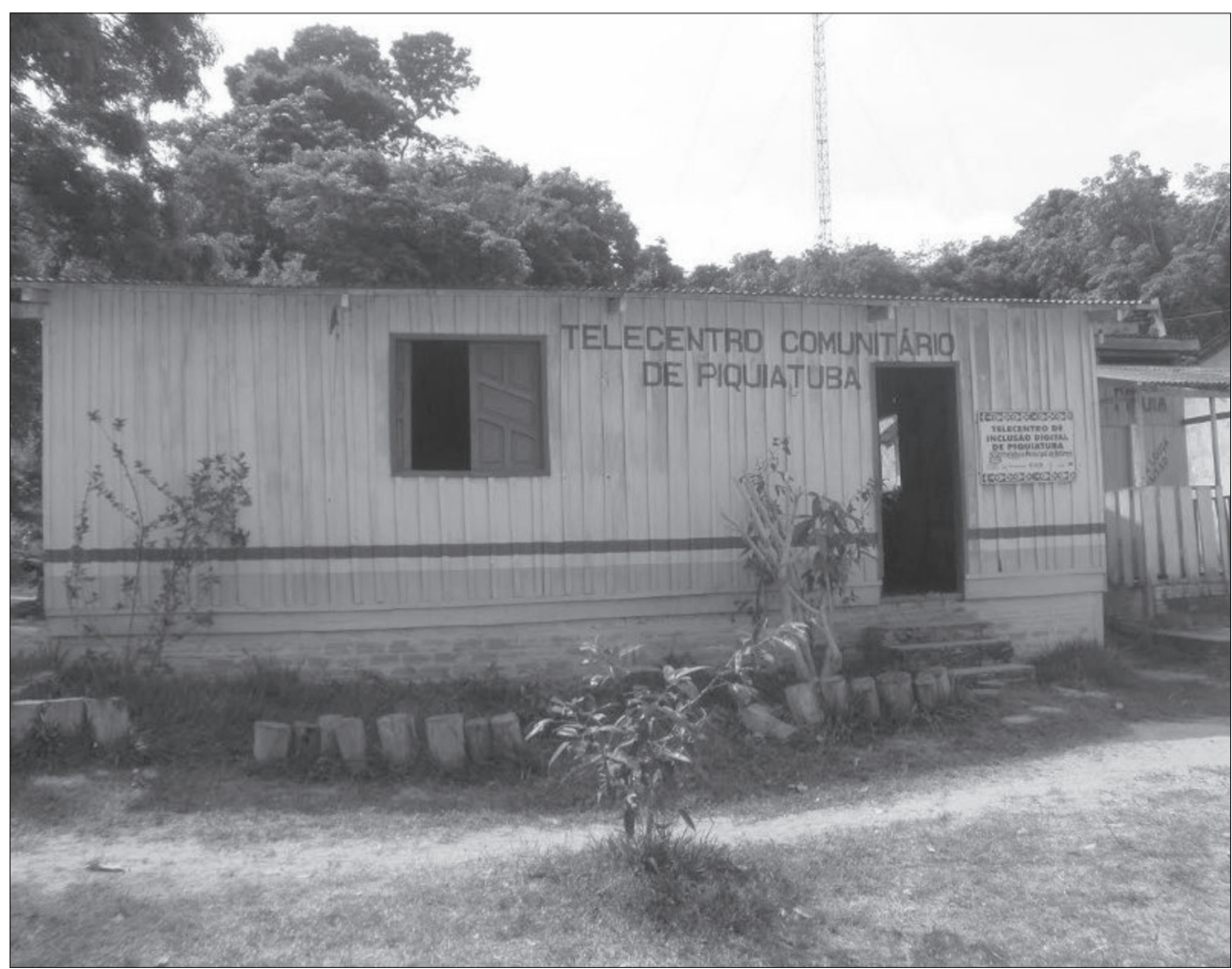

Photo 1. Patterns of community are significant for measures to respond to rural change, as any attempt to engage local actors in the delivery of rural development. Community telecenter in Piquiatuba, Pará state, Amazon Region, Brazil. Source: Field research, 2013.

ritory: information, integration, planning and action" (Clément, C. and Bryant, C. 2004, 191). Participation, cooperation, joint work and construction of partnerships are undertaken giving rise to networks of local actors who devise strategies of resistance, resilience or adaptation of rural communities to new global contexts (WiLson, G.A. 2012). A similar concern is present in assessments of environmental impacts and in socioeconomic policy in developing countries that highlight the need for integrating local knowledge into planning and evaluation of development projects (BRYANT, C. et al. 2004).

At the local level, different rural patterns are also driven by diverse elements, and are shaped by various social, economic, and political forces according to different social and geographical contexts (MARsDen, T. 2003). The focus for rural studies has been placed on the local community level, as it is at this level that spatiality of resilience are implemented 'on the ground' (MCCARTHY, J. 2005; Parnwell, M.J. 2007; Wilson, G.A. 2010). The justification for this is both analytical and pragmatic. As commentators such as Agrawal, A. and Gibson, C.C. (1999) or Wilson, G.A. (2012) emphasized, over the past two decades, there has been resurgence in attention to community as a critical arena for addressing a range of issues, including societal pathways of change. To address this issue, this article questions how rural communities from developing world address resilience in the context of rural change and globalization. 


\section{Rural change in the context of globalization}

Accumulation crises in capitalist societies provoke periodic and, sometimes, radical restructuring of productive processes in order to establish new investment opportunities, a consequence of which is the reassessment of resources and spaces previously deemed unproductive or marginal. For several reasons, some rural areas, previously deemed places of declining economic activities, start to be seen as investment frontiers (MARSDEN, T. et al. 1993) and rural elements, which until then had little social or economic value and are reset and re-functionalized. Good examples are the 'commoditization' of nature, landscapes for tourism and environmental preservation, production of healthy foods and creation of rural leisure activities, all of which are part and partial of globalization.

A recurrent theme in rural studies has been the significance of diverse globalization processes as drivers of rural change. The variety of contexts in which globalization has been encountered - economic production, services and tourism, migration, and environmental protects - points to the multiple character of globalization. As a result, new directions in rural studies have called for researches that examine the impact of globalization on everyday life (Woods, M. 2012). Methods in rural geography in the era of globalization have provided wider theoretical frameworks and insights into the rural domain through in-depth studies and bottom-up model and multidimensional approaches (e.g. political economy, cultural studies and political ecology) (Table 1).

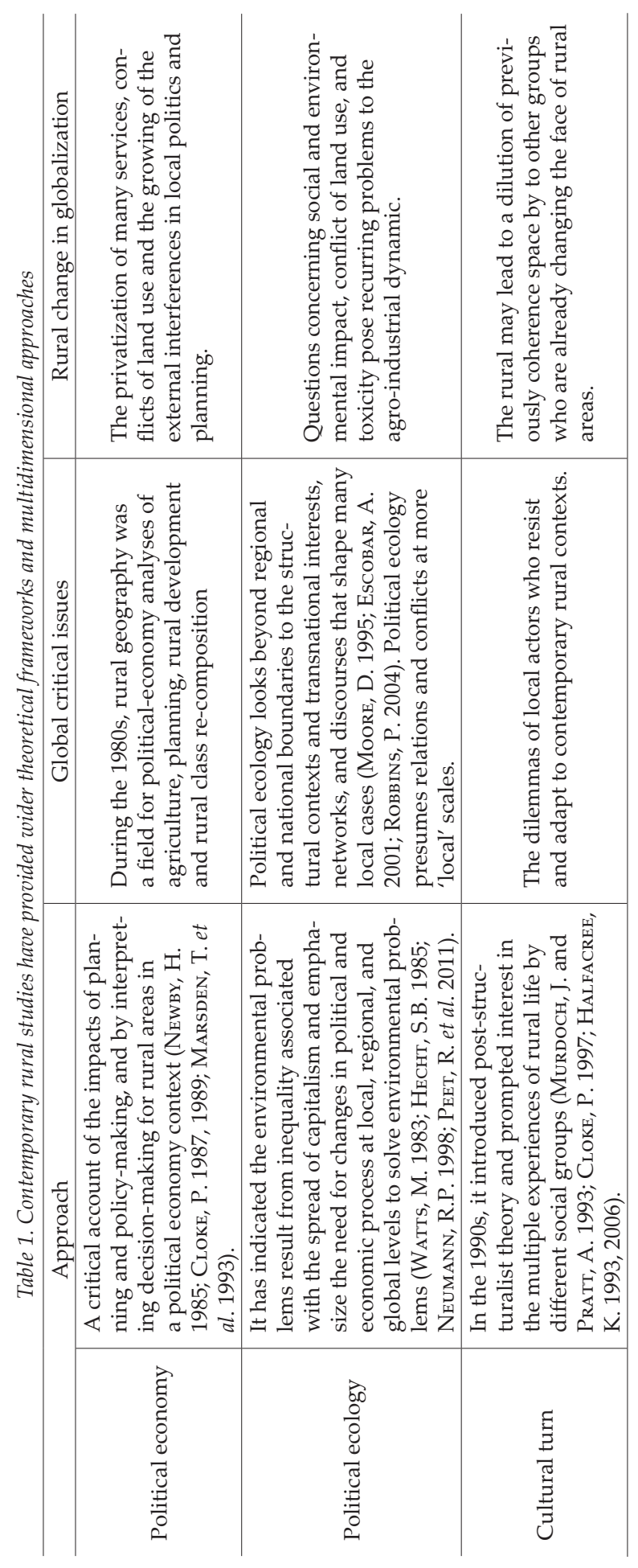


Globalization has changed the relationship between urban and rural areas. The city and the countryside modify their dynamics through the intermediation of global exogenous factors, strengthening local-global direct connections. In this way, the rural is not reduced to a mere geographical location, it becomes a place where occurs the mediation of macro social and economic operations directly articulated to global processes. The answers to these processes, however, are different in the political and social content interacting with the exploration of local resources that depends on the characteristics and the relationships of the countryside in the regional context (CLOKE, P. 1990; Marsden, T. et al. 1993).

The process of globalization has a pervasive influence in transforming rural economies and societies, with implications for the major societal challenges of environmental change and resource security. However, in comparison to studies of the global city, relatively little research has focused on the 'global countryside' (Woods, M. 2007), and existing research lacks integration. Thus, contemporary rural studies have developed an integrated perspective by drawing on relational analysis to focus on the actual mechanics by which rural localities are 'remade' through engagement with globalization processes, examining the mediating effect of national and regional context and the opportunity for local interventions.
Woods, M. (2007) posited the notion of the 'global countryside' as a geographical and conceptual counterpoint to the 'global city'. The global countryside is presented as a space that has become increasingly integrated and interconnected through globalization process. This emergent global countryside is not a uniform, homogenous space, but rather is differentially articulated, and contested, through particular rural places. According to Woods, M. (2007), the concept of place is a space of interconnections reconstituted by globalization into hybrid dimensions of transformations and interactions between local, national and global actors.

Wilson's work on community resilience and transitions particularly pointed towards the fact that the notion of exogenous macroscalar 'transitional corridors' shaped by national and global decision-making processes, and analysed how such corridors influence community resilience (WILson, G.A. 2012). He argued that the critical literature often portrays macro-scalar corridors as 'negative' for innovation. Then analysed the importance of macro-scalar lock-in effects external (i.e. globalization) to communities and discussed how these can shape community pathways and resilience in both positive and negative ways (Table 2).

With regard to experiments in local development in different parts of the world, the Sustainability of Rural Systems Commission

Table 2. Contemporary rural change, concepts and global critical issues

\begin{tabular}{|c|c|c|}
\hline Concept & Debate & Global critical issues \\
\hline \multicolumn{3}{|c|}{ The global countryside } \\
\hline $\begin{array}{l}\text { Woods, M. 2007, } 2011 . \\
\text { Cheshire, L. and Woods, M. } 2013 . \\
\text { McDonAGH, J. et al. } 2015 .\end{array}$ & $\begin{array}{l}\text { Rural space that has become } \\
\text { increasingly integrated and inter- } \\
\text { connected through globalization } \\
\text { process }\end{array}$ & $\begin{array}{l}\text { Globalization alters employment } \\
\text { opportunities, raise or depress } \\
\text { income levels, and change pat- } \\
\text { terns of local service provision. } \\
\text { The impact of globalization on } \\
\text { everyday life in a rural context. }\end{array}$ \\
\hline \multicolumn{3}{|c|}{ Rural resilience } \\
\hline $\begin{array}{l}\text { Wilson, G.A. 2010, } 2012 . \\
\text { McManus, P. et al. } 2012 . \\
\text { Scott, M. } 2013 . \\
\text { Welsh, M. } 2014 .\end{array}$ & $\begin{array}{l}\text { The potential of social innovation } \\
\text { and collective agency at the com- } \\
\text { munity scale in exploring new } \\
\text { development }\end{array}$ & $\begin{array}{l}\text { An exploration of farming and } \\
\text { its role for rural resilience. The } \\
\text { various aspects of community } \\
\text { resilience within rural localities }\end{array}$ \\
\hline
\end{tabular}


of the International Geographical Union has produced a number of studies which treat rural restructuring in different countries (e.g. Bicalho, A.M.S.M. and Hoefle, S.W. 2004; Frutos, L.M. et al. 2010; KIM, D. et al. 2013; Bicalho, A.M.S.M. and Laurens, L. 2014). These studies focus on the influence of globalization, internationalization of agriculture, urbanization of rural areas, the rise of multifunctionality, strategies for promoting sustainable rural development and territorial governance, all linked to the new functions of rural space and the dilemmas of local actors who resist and adapt to new rural contexts.

\section{(Re)positioning debates surrounding rural change and globalization}

In recent years, researchers have displayed an interest in understanding the dynamics of rural spaces in developing regions of the world which are also affected by global processes in different ways and the sum result is great global spatial diversity (MARsDen, $\mathrm{T}$. 2003; Wilson, G.A. and RigG, J. 2003; RigG, J. 2006; Wilson, G.A. 2007; Woods, M. 2007; Bryant, C. et al. 2008; Ploeg, J.D. van Der et al. 2010). Recognition of the global inter-connection and inter-dependency of rural places points to a dismantling of the separation between rural research on the global north and rural research on the global south, and the promotion of more transnational research. As Woods, M. (2005, 2011), in particular, emphasized, although rural geographers often consider the global north and south separately, in our ever shrinking world society these two paradigms are often coming together.

Multidimensional and multidirectional perspectives have indicated that, over time, rural areas in developing countries increase embeddedness into a globalized rural world (Wilson, G.A. and RigG, J. 2003; RigG, J. 2006; PARnwell, M.J. 2007; Wilson, G.A. 2008). This article suggests that the repercussion of the challenges for rural areas in the developing world in the early twenty-first century, such as the political economies of new strategies for economic development and the resilience of rural communities, should receive more attention. Traditionally, a lot of research in rural studies has been empirical in nature, but over the past years a more critical rural social science has developed which has employed a range of conceptual theories in its analysis, including political-economic concepts and post-structuralism (e.g. 'Handbook of Rural Studies' edited by Cloke, P. et al. 2006).

The complexity of spatial restructuring present in the developing world in the era of globalization contributes to better understanding the contemporary rural, going beyond the view of inert spaces only subject to external interferences. CUtTer, S.L. et al. (2008) and Wilson, G.A. (2010, 2012) indicated that there is a need for further research in these arenas, arguing that despite metaphorical and theoretical models which have progressed to the operational stages, processes of resilience should be measured and monitored at local level.

Rural transformation in the global world is a hybrid and contested process, that involves actors and forces operating at multiple scales, and which echoes elements of rural restructuring in both the developed world of Europe and North America and the developing world, yet has distinctively different characteristics. Accelerating globalization processes exacerbate the already precarious situation in many rural districts in both the global North and South, as virtually all areas are affected by global propelling forces often outside the control of regional and national regulatory structures.

In addition, agriculture no longer necessarily forms the essential backbone for rural development, and instead rural spaces in both the global North and South are characterised by complex, multidimensional and hybrid development path ways in which questions about the right and wrong development trajectories are increasingly difficult to answer.

Woods, M. (2011) has highlighted how the global tipping point has come with rapid urbanization in Brazil, China and India, and other fast-growing countries of the global south. (Photo 2). Yet, the population shift 

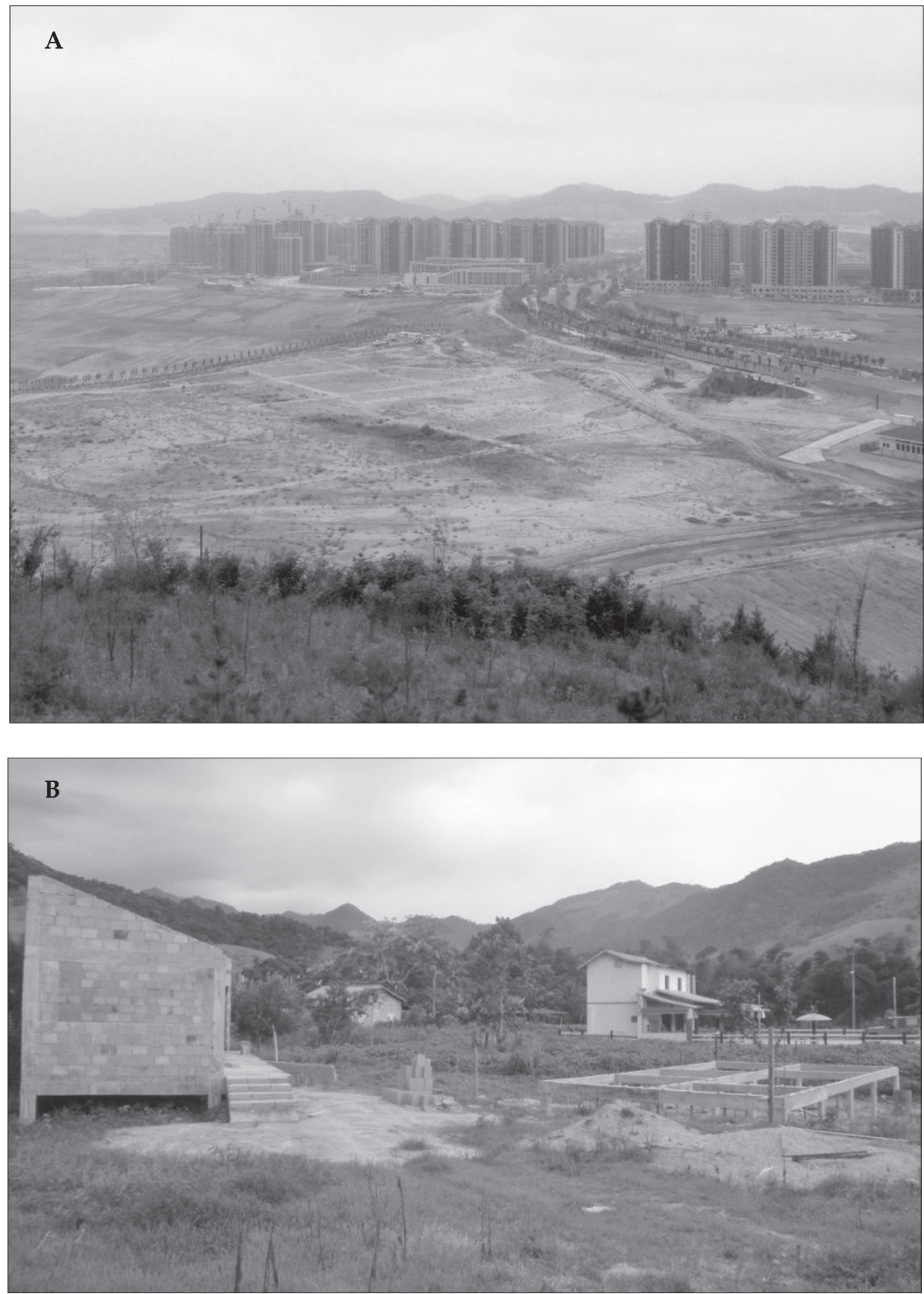

Photo 2. Questions about how rural land use should be planned and regulated have also long-standing concerns geographers: Yan'an New District, Shaanxi Province, China, 2016 (A). Cachoeiras de Macacu, Rio de Janeiro state, Brazil, 2013 (B). Sources: Field research in 2016 (A) and in 2013 (B). 
does not in itself necessarily mean that the rural has been eclipsed, or become irrelevant. On the contrary, as rural studies has demonstrated, the rural continues to be central to many of the key issues confronting the world today, and the study of rural geographies is arguably as important as ever.

Hu, Z. and Rahman, S. (2015), based on an in-depth case study of a rural community, pointed to the fact that the contemporary state of Chinese smallholder agriculture and changes that it has been experiencing in the context of socio-economic transition through the lens of three main economic drivers: livelihood diversification, market conditions and government interventions. Results reveal that the change in China smallholder agriculture has been complex and multidimensional. All three factors exert profound influence and shape the current state of Chinese agriculture. Massive rural-urban migration has resulted in labour shortages, which in turn have led to a reduction in agricultural diversity and land use intensity.

Understanding the economic drivers of smallholder agriculture is important in the present day, because both the media and academia have recently raised grave concerns regarding a crisis of smallholder agriculture driven by massive nonfarm employment and expressed doubts about an argument used in both policy and academic spheres for reform towards large-scale capitalist agriculture.

Studies have illustrated that agricultural change may involve multidimensional and often parallel processes, which are not only labour-driven intensification, but also technology driven intensification (PLOEG, J.D. vAN DeR 2008; Ploeg, J.D. van der et al. 2013). As BRookfIELD, H. (2001) rightfully contended, driven by livelihood diversification, agricultural change has taken multiple pathways so that intensification alone can never fully capture the complexity of the processes involved. He has highlighted the capability of smallholders and further argues that the key for survival and successful change of smallholder agriculture has been adaptation and innovation. In the context of Asian deagrari- anization, RIGG, J. (2001) indicated that both intensification and disintensification have occurred in Asian rural change. The theory of rural change in developing countries so far has underscored at least two points. First, change is complex, diverse and multidimensional. Second, change is context dependent and can be affected in diverse pathways.

\section{Conclusions}

The repercussion of the challenges for rural areas in the early twenty-first century, such as the political economies of new strategies for economic development based on the use and management of resources and the resilience of rural communities to macro-scalar effects, have been paid little academic attention (WILson, G.A. 2012; Woods, M. 2012). This article questions the changes of contemporary rural space under the context of its socio-economic integration into global capitalism.

Most of the studies have explained and interpreted the causality between globalization and factors of rural change in a linear way and therefore produced homogenous conclusions. Consequently, to more comprehensively interpret the effects of different socio-economic and political change drivers on rural dynamics, the main aim in contemporary rural studies is to explore the processes through which differential factors have affected the rural with a focus in how different degrees of rural-urban interaction and global influences give rise to multifunctional diversity and spatial complexity.

However, the literature of rural geography in developing countries still is constituted mainly by agricultural economies and analysis of agricultural policies, such as institutional change, agricultural technological development, rural-urban migration, which emphasize the empirical evidence of how structural factors affect agricultural production (Delgado, G.D. 2012; Ioris, A.A.R. 2012). At present, great enthusiasm is expressed by the media and governments concerning economic growth directly related to the spread of 
agribusiness-scale production in the countryside in developing countries such as Brazil.

In contrast, academics have explored agroindustrial food networks through a critical perspective, placing agribusiness-scale production within a mass production model which includes volume and standardization (Bernardes, J.A. and Freire Filho, O.L. 2005; Bernardes, J.A. 2015; Hosono, A. et al. 2016). Questions about social and environmental impact, conflict of land use, and toxicity pose recurring problems to this agroindustrial dynamic. In these cases, the study of globalization in a rural context has commonly focused on commodity chains and its contradictions.

This article argues that the complexity of rural areas and its spatial diversity contribute to better understanding of the multidirectional and multidimensional paths in globalization, going beyond the view of economic space as only subject to external interferences that demand resources. In the case of developing countries, little attention has been paid to investigating the rural space by combining macro-political economy with the analysis of local strategies. In conclusion, I have drawn insights for advancing social resilience in the global countryside through an analysis of rural restructuring related to the current global changes 'on the ground'. It attempts to develop a connection between rural change, rural community resilience in developing countries and broader rural studies in the context of globalization.

Acknowledgement: The Doctoral Career Development Scholarship by CAPES Foundation, Ministry of Education of Brazil is gratefully acknowledged.

\section{REFERENCES}

Agrawal, A. and Gibson, C.C. 1999. Enchantment and disenchantment: the role of community in natural resource conservation. World Development 27. 629-649.

Bernardes, J.A. 2015. Novas fronteiras do capital no Cerrado: dinâmica e contradições da expansão do agronegócio na região Centro-Oeste, Brasil. Scripta Nova (Barcelona) 19. 1-28.
Bernardes, J.A. and Freire Filho, O.L. 2005. Geografias da soja: BR-163 - Fronteiras em mutação. Rio de Janeiro, Arquimedes.

Bicalho, A.M.S.M. and Hoefle, S.W. eds. 2004. The Regional Dimension and Contemporary Challenges to Rural Sustainability. Rio de Janeiro, Laget-UFRJ/ CSRS-UGI.

Bicalho, A.M.S.M. and Laurens, L. eds. 2014. The Changing Face of the Contemporary Countryside. Rio de Janeiro, Garamond.

Bicalho, A.M.S.M., Bryant, C., Laurens, L., Oort, G., Macura, V., Winkler, J. and TAKahashi, M. 1998. Sustentabilidade na interface rural-urbana - questões centrais à pesquisa. Revista da Pós-Graduação em Geografia da UFR -PPGG 2. 106-119.

BRookfIELD, H. 2001. Intensification, and alternative approaches to agricultural change. Asia Pacific Viewpoint 42. (2-3): 181-192.

Bryant, C. 1997. L' agriculture périurbaine: l' économie politique d'un espace innovateur. Cahiers Agricultures 6. 125-130.

Bryant, C., Doyon, M., Frej, S., Granjon, D. and Clément, C. 2004. The integration of environment into sustainable development practice and discourse through citizen participation and the mobilisation of local knowledge. In The Regional Dimension and Contemporary Challenges to Rural Sustainability. Eds.: Bicalho, A.M.S.M. and Hoefle, S.W., Rio de Janeiro, Laget-UFRJ/CSRS-UGI, 14-25.

Bryant, C.R., Makhanya, E. and Herrmann, T.H. 2008. The Sustainability of Rural Systems in Developing Countries. Laboratoire de développement durable et dynamique territorial - Département de Géographie. Montreal, Université de Montréal.

Cheshire, L. and Woods, M. 2013. Globally engaged farmers as transnational actors: navigating the landscape of agri-food globalization. Geoforum 44. 232-242.

Clément, C. and Bryant, C. 2004. Urban fringe horticulture in the Ottawa. In The Regional Dimension and Contemporary Challenges to Rural Sustainability. Eds.: Bicalho, A.M.S.M. and Hoefle, S.W., Rio de Janeiro, Laget-UFRJ/CSRS-UGI, 187-202.

Cloke, P. ed. 1987. Rural planning: policy into action? London, Harper and Row.

Cloke, P. 1989. Rural geography and political economy. In New models in Geography. Eds.: Peet, R. and Thrift, N., London, Unwin Hyman, 164-197.

Cloke, P. 1990. Political economy approaches and a changing rural geography. Rural History 1. 123-129.

Cloke, P. 1997. Country backwater to virtual village? Rural studies and 'the cultural turn'. Journal of Rural Studies 13. 367-375.

Cloke, P., Marsden, T. and Mooney, P. eds. 2006. Handbook of Rural Studies. London, Sage.

Cutter, S.L., Barnes, L., Berry, M., Burton, C., Evans, E., TAте, E. and WebB, J. 2008. A place-based model for understading community resilience to natural disasters. Global Environmental Change 18. 598-606. 
Delgado, G.D. 2012. Do capital financeiro na agricultura à economia do agronegócio: mudanças cíclicas em meio século (1965-2012). Porto Alegre, UFRGS.

EscobAR, A. 2001. Encountering development: the making and unmaking of the Third World. Princeton, Princeton University Press.

Frutos, L.M., Climent, E., Ruiz, E., Bicalho, A.M.S.M. and Laurens, L. eds. 2010. New Ruralities and Sustainable Use of Territory. Zaragoza, Prensas Universitarias de Zaragoza.

Halfacree, K. 1993. Locality and social representation: space, discourse and alternative definitions of the rural. Journal of Rural Studies 9. 1-15.

Halfacree, K. 2006. Rural space; constructing a threefold architecture. In Handbook of Rural Studies. Eds.: Cloke, P., Marsden, T. and Mooney, P., London, Sage. 44-62.

Неснт, S.B. 1985. Environment, development, and politics: capital accumulation and the livestock sector in Eastern Amazonia. World Development 13. 663-684.

Hosono, A., Rocha, C.M.C. and Hongo, Y. eds. 2016. Development for Sustainable Agriculture: the Brazilian Cerrado. New York, Palgrave Macmillan.

Hu, Z. and Rahman, S. 2015. Economic drivers of contemporary smallholder agriculture in a transitional economy: a case study of $\mathrm{Hu}$ Village from southwest China. Singapore Journal of Tropical Geography 36. 324-334.

Ioris, A.A.R. 2016. The politico-ecological economy of neoliberal agribusiness: displacement, financialisation and mystification. Area 48. (1): 84-91.

Kim, D., Firmino, A.M. and IchiKawA, Y. eds. 2013. Globalization and New Challenges of Agricultural and Rural Systems. Nagoya, University of Nagoya Press.

Marsden, T. 2003. The Condition of Rural Sustainability. Assen, Royal Van Gorcum.

Marsden, T., Murdoch, J., Lowe, P., Munton, R. and Flynn, A. 1993. Constructing the Countryside. London, UCL Press Ltd.

McCARTHY, J. 2005. Rural geography: multifunctional rural geographies - reactionary or radical? Progress in Human Geography 29. (6): 773-782.

McDonagh, J., Nienaber, B. and Woods, M. eds. 2015. Globalization and Europe's Rural Regions. Surrey, Ashgate.

McManus, P., Walmsley, J., Argent, N., Baum, S., Bourke, L., Martin, J., Pritchard, B. and Sorensen, T. 2012. Rural community and rural resilience: what is important to farmers in keeping their country towns alive? Journal of Rural Studies 28. 20-29.

Moore, D. 1995. Marxism, culture and political ecology. In Liberation ecologies. Eds.: Peet, R. and Watts, M., London, Routledge, 125-147.

Murdoch, J. and Pratt, A. 1993. Rural studies: modernism, postmodernism and the 'post-rural'. Journal of Rural Studies 9. 411-427.
Neumann, R.P. 1998. Imposing wilderness: struggles over livelihood and nature preservation in Africa. Berkeley, University of California Press.

Newby, H. 1985. Green and pleasant land? Social change in rural England. London, Hutchinson.

Parnwell, M.J. 2007. Neolocalism and renascent social capital in northeast Thailand. Environment and Planning D: Society and Space 25. 990-1014.

Peet, R., Robbins, P. and Watts, M. eds. 2011. Global Political Ecology. London, Routledge.

Pierce, J.T. 1998. Sustaining rural environments: widening communities of knowledge. Nederlandse Geografische Studies 244. 21-44.

Ploeg, J.D. van der 2008. The new peasantries: struggles for autonomy and sustainability in an era of empire and globalization. London, Earthscan.

Ploeg, J.D. van Der, Schneider, S. and Jingzhong, Y. 2010. Rural development reconsidered: building on comparative perspectives from China, Brazil and the European Union. Rivista di Economia Agraria 2. 163-190.

Ploeg, J.D., van der, Ye, J., Wu, H. and Wang, C. 2013. Peasant-managed agricultural growth in China: mechanisms of labour-driven intensification. International Journal of Sociology of Agriculture and Food 21. (1): 155-171.

PretTy, J.N. 1995. Regenerating agriculture: policies and practice for sustainability and self-reliance. London, Earthscan.

RIGG, J. 2001. More than the soil: rural change in Southeast Asia. Harlow, Pearson Education.

RIGG, J. 2006. Land, farming, livelihoods, and poverty: rethinking the links in the rural South. World Development 34. (1): 180-202.

Roвbins, P. 2004. Political ecology: a critical introduction. Oxford, Blackwell.

Robinson, G.M. 2004. Geographies of agriculture: globalisation, restructuring and sustainability. Harlow, Pearson.

SÁNCHEZ, G.P.Z. 2000. Las nuevas funciones del espacio rural. Ensayos Frohum 15. 1-12.

SÁnchez, H.A. 2012. Las prácticas agrícolas en las periferias metropolitanas: territorialización y sociabilidade en ámbitos de interfase urbano-rural en América Latina. In Território e sociabilidade: relatos latino-americanos. Eds.: MArtins, P., SÁnCHEz, H.A. and Welter, T., Florianopolis, UDESC, 27-54.

Sсотт, M. 2013. Resilience: a conceptual lens for rural studies? Geography Compass 7. (9): 597-610.

van Huylenbroek, G., Vandermeulen, V., MetTEPENNingen, E. and Verspecht, A. 2007. Multifunctionality of agriculture: a review of definitions, evidence and instruments. Living Reviews in Landscape Research 1. 5-43.

Watтs, M. 1983. Silent violence: food, famine and peasantry in Northern Nigeria. Berkeley, University of California Press. 
Welsh, M. 2014. Resilience and responsibility: governing uncertainty in a complex world. The Geographical Journal 180. 15-26.

Wilson, G.A. 2007. Multifunctional Agriculture: A Transition Theory Perspective. Wallingford, CABI.

Wilson, G.A. 2010. Multifunctional 'quality' and rural community resilience. Transactions of the Institute of British Geographers 35. (3): 364-381.

Wilson, G.A. 2012. Community Resilience and Environmental Transitions. London, Earthscan.

Wilson, G.A. and RigG, J. 2003. 'Post-productivist' agricultural regimes and the South: discordant concepts? Progress in Human Geography 27. (5): 605-631.
Woods, M. 2005. Rural Geography: processes, responses and experiences in rural restructuring. London, Sage. Woods, M. 2007. Engaging the global countryside: globalization, hybridity and the reconstitution of rural place. Progress in Human Geography 31. 485-507.

Woods, M. 2011. Rural. Abingdon, Routledge.

Woods, M. 2012. New directions in rural studies? Journal of Rural Studies 28. 1-4. 
